\title{
Searching for potential wood biomass for green energy feedstock: A study in tropical swamp-peat forest of Kutai Kertanegara, Indonesia
}

\author{
RUDIANTO AMIRTA ${ }^{1, \bullet}$, MUHAMMAD TAUFIQ HAQIQI ${ }^{1}$, SAPARWADI ${ }^{2}$, ELIS SEPTIA ${ }^{1}$, \\ DEWI MUJIASIH ${ }^{1}$, KRISNA ADIB SETIAWAN ${ }^{1}$, MUHAMMAD AFIF SEKEDANG ${ }^{1}$, \\ YULIANSYAH $^{1}$, AKHMAD WIJAYA ${ }^{2}$, BUDHI SETIYONO ${ }^{2}$, WIWIN SUWINARTI ${ }^{1}$ \\ ${ }^{1}$ Faculty of Forestry, Universitas Mulawarman. J1. Penajam, Kampus Gunung Kelua, Samarinda 75119, East Kalimantan, Indonesia. \\ Tel./fax.: +62-541-748683, "email: ramirta@fahutan.unmul.ac.id \\ ${ }^{2}$ Bioma Foundation. Jl. AW. Syahrani, Perumahan Ratindo F7-8, Samarinda 75124, East Kalimantan, Indonesia
}

Manuscript received: 22 April 2019. Revision accepted: 5 May 2019.

\begin{abstract}
Amirta R, Haqiqi MT, Saparwadi, Septia E, Mujiasih D, Setiawan KA, Sekedang MA, Yuliansyah, Wijaya A, Setiyono B, Suwinarti W. 2019. Searching for potential wood biomass for green energy feedstock: A study in tropical swamp-peat forest of Kutai Kertanegara, Indonesia. Biodiversitas 20: 1516-1523. Recently, much attention has been focused on finding suitable plant species, from different forest ecosystems, having the potential to be used as sources of renewable energy. Most of such information was reported from the lowland forest area and only limited information is available regarding swamp-peat forest species, including their energy potency. Therefore, in this paper, plant diversity and energy potency of swamp-peat forest wood biomass were studied to reveal their potential as green energy feedstock. Physico-chemical characterization of wood biomass was performed using the American Society for Testing and Material (ASTM) protocols. Twenty-seven species of plants, consisting of 23 trees and 4 shrubs, belonging to 19 families were identified, amongst which Shorea balangeran had the highest importance value index $(87.72 \%)$. The results showed that $T$. obovata exhibit the highest suitability to be used as energy feedstock indicated by the highest energy production of $4.60 \mathrm{MWh}$ per ton of dry biomass, followed by L. indica (4.56 MWh/ton), D. excelsa (5.52 MWh/ton), F. rukam (4.20 MWh/ton), P. galeata (3.66 MWh/ton), S. caudatilimbum (3.61 MWh/ton), A. elmeri (3.59 MWh/ton), G. nervosa (3.49 MWh/ton) and G. bancana (3.42 MWh/ton). The high density of wood species correlated with the high value of energy potency. In contrast, the fast-growing tree and shrub species, such as $K$. hospita (1.76 MWh/ton), C. odorata (1.36 MWh/ton) and O. sumatrana (1.17 MWh/ton), showed lower energy potency. The most dominant plant species, $S$. balangeran gave only $2.96 \mathrm{MWh}$ energy per ton of dry biomass and it was classified in the middle group of plant species suitable as green energy feedstock, along with other species, such as C. brachiata, C. rotundatus, $P$. javanicum, V. umbonata, L. speciosa, V. pinnata, and A. longifolius. Due to suitable energy properties, growth rate and also adaptability of this woody biomass, they can be exploited to support sustainable supply of biomass feedstock for the green electricity program in the study area.
\end{abstract}

Keywords: Biomass, feedstock, green energy, plant diversity, swamp-peat forest

\section{INTRODUCTION}

Currently, the concerns related to energy production from fossil fuels and associated environmental impacts are increasing. The issue of $\mathrm{CO}_{2}$ emission from burning of fossil fuels and global warming is being discussed seriously in many developed and developing countries (Han and Shin 2014; Kumar et al. 2015; García and Bacenetti 2019). Indonesia and many other national governments have declared to start production of energy and fuels from renewable sources, mainly biomass. These governments have realized that the bioenergy and biofuel industries will increase the amount of domestic supply of energy and fuels with decrease in subsidy available for promotion of the bioenergy and biofuels (Watanabe et al. 2008). Bioenergy was also developed to replace fossil fuels in energy production in order to decrease greenhouse gas emissions into the atmosphere (Jiankun et al. 2012; Routa et al 2012). The important idea behind this practice is that bioenergy does not cause any net carbon dioxide $\left(\mathrm{CO}_{2}\right)$ emissions. The net carbon dioxide $\left(\mathrm{CO}_{2}\right)$ emissions from bioenergy were considered to be zero based on the fact that the amount of $\mathrm{CO}_{2}$ released into the atmosphere during combustion is taken up again by the growth of the next generation plants (Wihersaari 2005; Lattimore et al. 2009).

Kalimantan province of Indonesia has vast areas of forest land with a high diversity of plant species. Massive wood biomass and other materials are produced here in various types of forest lands, such as low land forests, riparian forests and also swamp-peat forests. These forest materials consist of potential biomass feedstock for green energy production. However, even though the diversity of plant species and biomass resources are rich, lack of scientific information on their basic properties, functions, and suitability as the feedstock for energy production, is believed to be acting as the main barrier for effective utilization of the woody biomass (Amirta et al. 2016a). Understanding of the species diversity and richness, biomass productivity and its suitability to be used as the green energy feedstock is important not only for the sustainable supply of biomass-based energy for the community, but also for conserving and managing the swamp-peat forest itself. 
Recently, much attention has been focused on finding suitable renewable energy plant species through research activities including identification of suitable biomass species and analysis of productivity and energy-related properties which can provide high-energy outputs to replace conventional fossil fuel energy sources. Plant sources suitable as wood biomass for energy feedstock purposes can be planted in forest land, using silvicultural practices in the form of fast-growing plantations (Yudego et al. 2017). Fast growing and short rotation coppice (SRC) species are ideal options for increasing the supply of wood biomass. Fast growing ability and shorter rotation cycles allow higher planting densities and thus, higher biomass yields per unit land area (Dillen et al. 2013; Ghaley and Porter 2014). However, only a little information about fast growing and short rotation coppice wood biomass plant species from swamp-peat forests, including their energy potency, is available so far. Most of the information of energy plant species were reported from the lowland forest areas, such as Willow (Salix viminalis), Poplar (Populus trichocarpa),_ Black Locust (Robinia pseudoacacia), and also Acacia (Acacia melanoxylon) and Eucalyptus (Eucalyptus globulus) trees, commonly used in Denmark, Germany, Poland, Italy, New Zealand and other European countries (Sims et al. 2001; Sims and Venturi 2004; Fiala and Bacenetti 2012; Dillen et al. 2013; Ghaley and Porter 2014; Hauk et al. 2014; Haverkamp and Musshoff 2014; Krzyzaniak et al. 2015; Niemczyk et al. 2018). Similar situation exists in Indonesia forest energy sector where very limited number of plant species, such as Calliandra calothyrsus, Glyricidia sepium, Macaranga hypoleuca and Vitex pinnata are known as the energy feedstock (Amirta et al. 2016a; 2016b). Therefore, in this paper, an attempt was made to find out the diversity, productivity and suitability of tree and woody shrub species in the swamp-peat forests of East Kalimantan, Indonesia which has the potential be used as high-quality feedstock for sustainable green energy production.

\section{MATERIALS AND METHODS}

\section{Study area}

The current research was conducted in the swamp-peat forest area of Muara Siran village $\left(116^{\circ} 48^{\prime} 34.656^{\prime \prime} \mathrm{E}\right.$, 0³7'7.093” N), sub-district of Muara Kaman, Kutai Kertanegara District, Indonesia. The swamp-peat forest at Muara Siran village has an area of about 40,598 ha with the annual temperature of $24-30^{\circ} \mathrm{C}$, while the daily temperatures fluctuate between $3^{\circ} \mathrm{C}$ to $4^{\circ} \mathrm{C}$. The daily average ambient humidity was $80 \%, 90 \%$ in the morning and down to $70 \%$ in the afternoon. The annual precipitation was $2367.27 \mathrm{~mm}$, while the mean monthly precipitation ranged between $108.6 \mathrm{~mm}$ to $322.9 \mathrm{~mm}$.

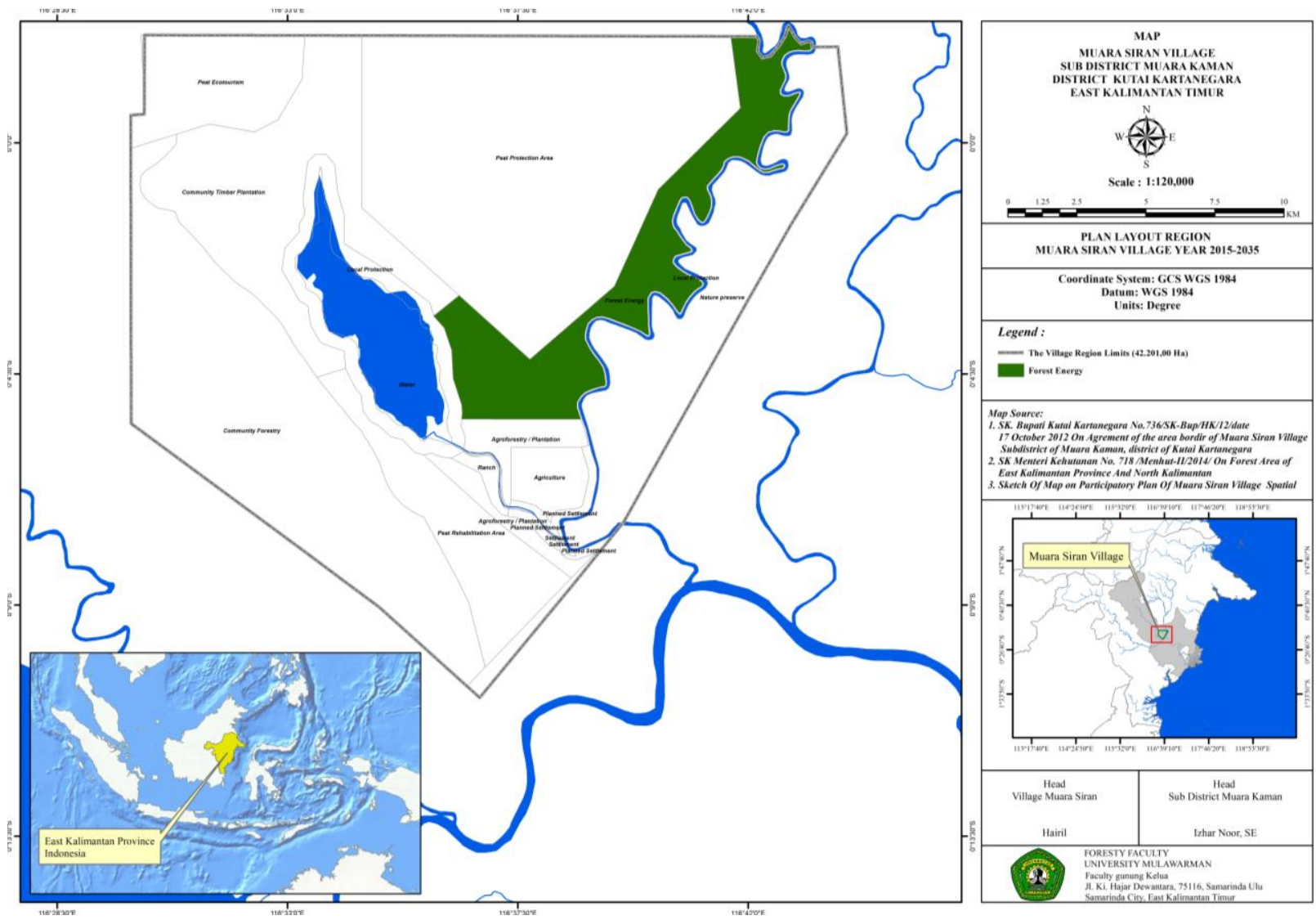

Figure 1. Research location at swamp-peat forest of Muara Siran, Kutai Kertanegara, East Kalimantan, Indonesia (116 48'34.656”E, 03’ $7.093 ” \mathrm{~N}$ ) 


\section{Diversity of plant species}

Ten sampling plots of the size of $20 \mathrm{~m} \times 20 \mathrm{~m}$ which were distributed around the swamp-peat forest of Muara Siran village, Kutai Kertanegara, East Kalimantan were used to collect the data about tree and woody shrub species richness that has the potential to be used as the green energy feedstock. In addition, the importance value index of plant species present in research area was calculated using the formula of Mueller-Dombois and Ellenberg as described and reported by Wiryono et al. (2016).

\section{Collection of biomass of plant species}

Biomass in the form of leaves and branches of tree and woody shrub species with diameter about 5-10 $\mathrm{cm}$ were collected from swamp-peat forest located at Muara Siran Village, Kutai Kertanegara District, East Kalimantan Province, Indonesia. The plant samples were identified at the Laboratory of Forest Dendrology, Faculty of Forestry, Mulawarman University, Samarinda, Indonesia. The wood samples were debarked, chipped, air dried, and used throughout this study.

\section{Physico-chemical characterization and energy potency of wood biomass}

The physicochemical characterization of the collected swamp-peat forest biomass was performed using the common analysis protocol of the American Society for Testing and Material (ASTM) D 7582-12. The various parameters analyzed consist of moisture content, ash value, density, volatile matter, and fixed carbon tests. In addition, to determine the elemental composition of wood biomass such as carbon $(\mathrm{C})$, hydrogen $(\mathrm{H})$ and oxygen $(\mathrm{O})$, and to find out the higher calorific value (HCV), the protocols proposed by Parikh et al. $(2005 ; 2007)$ was used. Then, the conversion ratio of solid to chip wood and biomass energy potency was calculated based on Francescato et al (2008).

\section{RESULTS AND DISCUSSION}

\section{Diversity of plant species}

Twenty-seven plant species consisting of 23 trees and 4 woody shrubs, which belong to 19 families, were listed from the ten plots sampled at swamp-peat forest of Muara Siran (Table 1). Among the tree and shrub species studied, Shorea balangeran had the highest importance value index $(87.72 \%)$, followed by Enterolobium cyclocarpum (60.10\%), Syzygium caudatilimbum (21.96\%), Carallia brachiata (19.31\%) and Kleinhovia Hospita (13.35\%), respectively (Table 1). S. balangeran (Dipterocarpaceae) with highest density and frequency was dominant among all plant species in the swamp-peat forest of Muara Siran. Myrtaceae emerged as the family with a maximum of three plant species identified in this study. These species are: $S$. caudatilimbum, S. chloranthum and T. Obovata. Almost similar with this finding, Thomy et al. (2018) and Yulisma et al. (2018) reported that the most dominant species in
Tripa peat swamp forest, Aceh have also belonged to Myrtaceae and Dipterocarpaceae. The dominant presence of Myrtaceae members may be related to their genetic and adaptability factors (Yulisma et al. 2018).

In general, it was found that the plant species were grown using two different regeneration systems, i.e., natural and artificial, that played an important role in revegetation, sustainable production and also conserving the swamp-peat forest ecosystem. The tree and shrub plant species of swamp-peat forest were also used by local community to support their biomass need for many purposes. The plant biomass of many species such as $A$. dumosa, A. elmeri, A. longifolius, C. rotundatus, $C$. brachiata, F. rukam, S. balangeran, T. obovata, V. pinnata, and $V$. umbonata was used as firewood, construction materials and for making furniture. In addition, G. nervosa and $K$. hospita were used traditionally as herbal medicine. Recently, the active compound of $K$. hospita was reported as a potential herbal medicine for curing liver cancer (anticancer), along with seven species of Macaranga (Arung et al. 2009; 2018).

\section{Physico-chemical analysis of swamp-peat forest plant species}

The use of biomass species for energy purposes should be carefully evaluated, analyzing logistical aspects of their location, transport, biomass heterogeneity and also storage. In addition, appropriate physicochemical and energy properties should be known. Accordingly, physicochemical characteristics of tree and shrub plant biomass collected from swamp-peat forest of Muara Siran were analyzed. The results demonstrated that the average of green moisture contents (after cutting) and wood densities of swamp-peat forest biomass were $43.41 \%$ and $0.58 \mathrm{~g} / \mathrm{cm}^{3}$, respectively (Table 3). It was found that, after chipping and air drying processes, the average of moisture content of wood biomass decreased significantly from $43.41 \%$ to $11.11 \%$. Chipping and air drying were effectively reduced the moisture content from the wood biomass as much as expected. The low moisture content (MC) of wood chip was appropriate to the requirement for biomass energy feedstock (MC $\leq 15 \%$ ). Thus, similar to some earlier reports, we also proved that chipping and air drying effectively reduced the moisture content from the wood biomass (Pérez et al. 2014; Sixto et al. 2015; Amirta et al. 2016a). According to earlier reports of McKendry (2002), Brammer and Bridgwater (2002), Pereira et al. (2012) and Pérez et al. (2014), this feature favors thermochemical conversion since high moisture content harms the performance of the conversion systems. It is possible to burn any type of biomass, but in practice, combustion is feasible only for biomass with a moisture content of $<50 \%$, unless the biomass is pre-dried. Further, the lower moisture content of the biomass (less than 30\%) is also suitable for the gasification process (McKendry 2002; Widjaya et al. 2018). 
Table 1. Plant species collected from the sampling plots located at swamp peat forest of Muara Siran, Kutai Kertanegara, East Kalimantan, Indonesia

\begin{tabular}{|c|c|c|c|c|c|}
\hline Plant species & Family & Local name & Category & Utilization & $\begin{array}{l}\text { Regene- } \\
\text { ration }\end{array}$ \\
\hline Adinandra dumosa Jack & Pentaphylacaceae & Kayu harang & Tree & Firewood & Artificial \\
\hline Alseodaphne elmeri Merr. & Lauraceae & Medang & Tree & Firewood & Artificial \\
\hline Artocarpus longifolius Becc. & Moraceae & Terap hutan & Tree & Construction & Natural \\
\hline Cananga odorata (Lam.) Hook.f. \& Thomson & Annonaceae & Kenanga & Tree & Medicine & Natural \\
\hline Carallia brachiata (Lour.) Merr. & Rhizophoraceae & Bakau & Tree & Furniture & Artificial \\
\hline Combretocarpus rotundatus (Miq.) Danser & Anisophylleaceae & Perepat & Tree & Construction & Artificial \\
\hline Dillenia excelsa (Jack) Martelli ex Gilg. & Dilleniaceae & Simpur & Tree & Construction & Artificial \\
\hline Dracontomelon dao (Blanco) Merr. \& Rolfe & Anacardiaceae & Sengkuang & Tree & Furniture & Natural \\
\hline Enterolobium cyclocarpum (Jacq.) Griseb. & Fabaceae & Sengon buto & Tree & Firewood & Artificial \\
\hline Eurya nitida Korth. & Pentaphylacaceae & Bunga & Shrub & Firewood & Natural \\
\hline Ficus hispida L.f. & Moraceae & Kebolo & Shrub & Firewood & Artificial \\
\hline Flacourtia rukam Zoll. \& Moritzi & Salicaceae & Rukam & Tree & Furniture & Artificial \\
\hline Garcinia bancana Miq. & Clusiaceae & Asam gendis & Tree & Firewood & Natural \\
\hline Garcinia nervosa Miq. & Clusiaceae & Manggis hutan & Tree & Medicine & Natural \\
\hline Kleinhovia hospita L. & Malvaceae & Tahongai & Tree & Medicine & Natural \\
\hline Lagerstroemia speciosa (L.) Pers. & Lythraceae & Bungur & Tree & Firewood & Natural \\
\hline Leea indica (Burm. f.) Merr. & Vitaceae & Mali & Shrub & Medicine & Natural \\
\hline Litsea robusta Blume & Lauraceae & Tiju & Tree & Construction & Natural \\
\hline Octomeles sumatrana Miq. & Tetramelaceae & Binuang & Tree & Construction & Natural \\
\hline Pternandra galeata Ridl. & Melastomataceae & Temberas & Tree & Firewood & Natural \\
\hline Pterospermum javanicum Jungh. & Malvaceae & Bayur & Tree & Construction & Artificial \\
\hline Shorea balangeran Burck & Dipterocarpaceae & Kahoi & Tree & Construction & Natural \\
\hline Syzygium caudatilimbum (Merr.) Merr. \& L. & Myrtaceae & Bluma & Tree & Construction & Natural \\
\hline Syzygium chloranthum (Duthie) Merr. \& L.M.Perry & Myrtaceae & Bumbun & Shrub & Construction & Natural \\
\hline Tristaniopsis obovata (Benn.) Peter G.Wilson \& J.T.Waterh. & Myrtaceae & Pelawan & Tree & Construction & Natural \\
\hline Vatica umbonata Burck & Dipterocarpaceae & Mas intan & Tree & Construction & Natural \\
\hline Vitex pinnata L. & Lamiaceae & Laban & Tree & Firewood & Natural \\
\hline
\end{tabular}

Table 2. Top five plant species based on their importance value index in the study area, Muara Siran, Kutai Kertanegara, East Kalimantan, Indonesia

\begin{tabular}{lllrrrr}
\hline Plant species & Family & Local name & Rdo & \multicolumn{1}{c}{ RF } & RDe & IVI \\
\hline Shorea balangeran & Dipterocarpaceae & Kahoi & 45.67 & 12.50 & 29.55 & 87.72 \\
Enterolobium cyclocarpum & Fabaceae & Sengon buto & 41.69 & 2.50 & 15.91 & 60.10 \\
Syzygium caudatilimbum & Myrtaceae & Bluma & 1.50 & 10.00 & 10.45 & 21.96 \\
Carallia brachiata & Rhizophoraceae & Bakau & 5.22 & 5.00 & 9.09 & 19.31 \\
Kleinhovia hospita & Malvaceae & Tahongai & 1.99 & 5.00 & 6.36 & 13.35 \\
\hline
\end{tabular}

Note: Rdo: relative dominance; RF: relative frequency; Rde: relative density; and IVI: importance value index

The results of this study showed that biomass of plant species of swamp-peat forest in Muara Siran may be classified into three different classes of wood density: low, middle and high densities that related to their growing ability, basic properties and also characteristic of each species studied. Among 27 plant species studied, we found that 4 species belonged to low density $\left(0.2-0.4 \mathrm{~g} / \mathrm{cm}^{3)}, 12\right.$ species to middle-density group $\left(0.4-0.6 \mathrm{~g} / \mathrm{cm}^{3}\right)$, while other 11 species to high-density group $\left(0.6>0.9 \mathrm{~g} / \mathrm{cm}^{3}\right)$ of wood plant species. The species with low and middle density of wood biomass, such $O$. sumatrana, $C$. odorata, $K$. hospita, and E. Cyclocarpum, positively correlated with their high-speed growth ability and they commonly belonged to pioneer plant species. The low-density biomass will consume fast in the reactor (gasifier/burner). Moreover, the low density of biomass (bulky) will also lead to high transport and storage costs, and in many cases, it is associated with high humidity that can make it impossible to be used (de Oliveira et al. 2013; Widjaya et al. 2018; Albashabsheh and Stamm 2019). In contrast, the species with high density of biomass, such as $P$. galeata, $D$. excelsa, T. obovata, and L. Indica, generally required longer time to grow and mature. In line with the previous studies, physicochemical properties of biomass commonly varied with plant species, and it will greatly affect the utilization of the resources (Vassilev et al. 2010). 
Table 3. Moisture content (MC), wood density and conversion ratio of solid wood to wood chip of plant species collected from swamppeat forest of Muara Siran, Kutai Kertanegara, East Kalimantan, Indonesia

\begin{tabular}{|c|c|c|c|c|c|}
\hline \multicolumn{2}{|c|}{ Plant species } & \multirow{2}{*}{$\begin{array}{l}\text { Moisture content } \\
(\text { green wood) }(\%)\end{array}$} & \multirow{2}{*}{$\begin{array}{l}\text { Moisture content } \\
\text { (wood chip) }(\%)\end{array}$} & \multirow{2}{*}{$\begin{array}{l}\text { Wood } \\
\text { density } \\
\left(\mathrm{g} / \mathrm{cm}^{3}\right)\end{array}$} & \multirow{2}{*}{$\begin{array}{c}\text { Wood chip } \\
\text { conversion ratio } \\
\left(\mathrm{kg} / \mathrm{m}^{3}\right)\end{array}$} \\
\hline Latin name & Local name & & & & \\
\hline Adinandra dumosa & Kayu harang & 41.04 & 11.08 & 0.53 & 266 \\
\hline Alseodaphne elmeri & Medang & 41.40 & 8.67 & 0.67 & 336 \\
\hline Artocarpus longifolius & Terap hutan & 39.22 & 12.99 & 0.55 & 276 \\
\hline Cananga odorata & Kenanga & 52.36 & 12.42 & 0.29 & 146 \\
\hline Carallia brachiata & Bakau & 52.47 & 10.16 & 0.60 & 301 \\
\hline Dillenia excelsa & Simpur & 41.17 & 10.54 & 0.88 & 442 \\
\hline Dracontomelon dao & Sengkuang & 41.78 & 10.75 & 0.62 & 311 \\
\hline Enterolobium cyclocarpum & Sengon buto & 37.29 & 12.77 & 0.40 & 201 \\
\hline Eurya nitida & Bunga & 51.32 & 11.45 & 0.51 & 256 \\
\hline Ficus hispida & Kebolo & 60.10 & 13.33 & 0.49 & 246 \\
\hline Flacourtia rukam & Rukam & 43.94 & 9.97 & 0.67 & 336 \\
\hline Garcinia bancana & Asam gendis & 41.11 & 11.58 & 0.67 & 336 \\
\hline Kleinhovia hospita & Tahongai & 43.76 & 14.18 & 0.34 & 171 \\
\hline Lagerstroemia speciosa & Bungur & 50.56 & 12.44 & 0.55 & 276 \\
\hline Leea indica & Mali & 28.71 & 8.46 & 0.92 & 462 \\
\hline Litsea robusta & Tiju & 44.12 & 11.20 & 0.53 & 266 \\
\hline Octomeles sumatrana & Binuang & 49.35 & 7.43 & 0.22 & 110 \\
\hline Pternandra galeata & Temberas & 35.37 & 12.16 & 0.72 & 362 \\
\hline Pterospermum javanicum & Bayur & 38.77 & 9.36 & 0.51 & 256 \\
\hline Shorea balangeran & Kahoi & 47.74 & 10.18 & 0.59 & 296 \\
\hline Syzygium caudatilimbum & Bluma & 42.73 & 10.74 & 0.68 & 342 \\
\hline Syzygium chloranthum & Bumbun & 52.36 & 14.27 & 0.51 & 286 \\
\hline Tristaniopsis obovata & Pelawan & 30.42 & 9.82 & 0.90 & 452 \\
\hline Vatica umbonata & Mas intan & 37.63 & 10.35 & 0.57 & 286 \\
\hline \multirow[t]{2}{*}{ Vitex pinnata } & Laban & 38.31 & 9.61 & 0.57 & 286 \\
\hline & Average & 43.41 & 11.11 & 0.58 & 294 \\
\hline
\end{tabular}
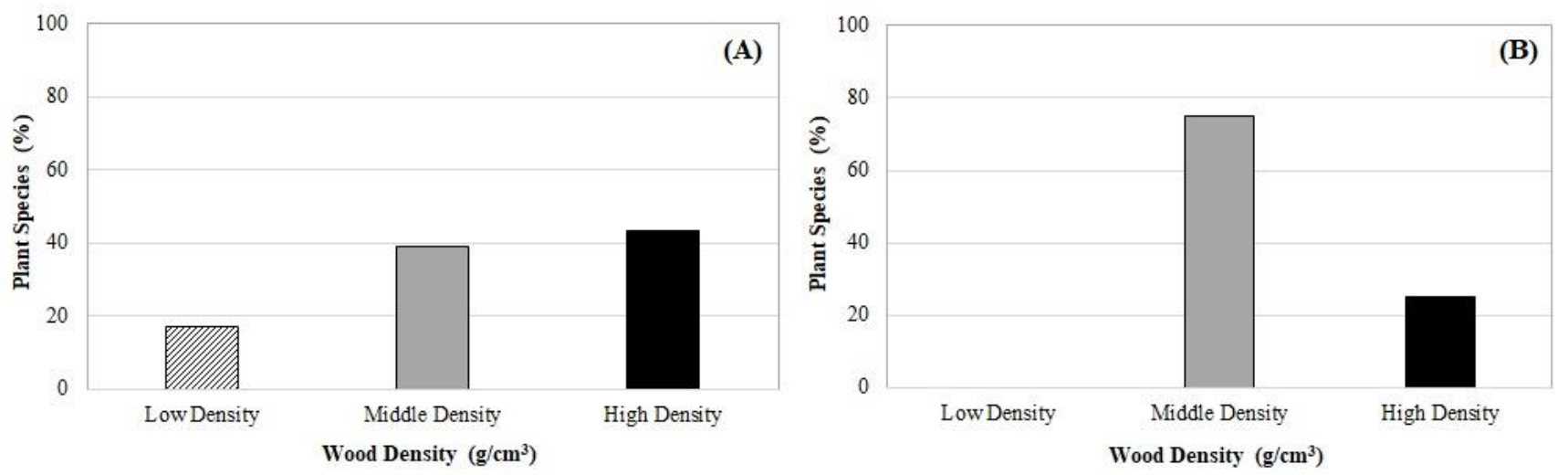

Figure 2. Wood density comparison among (A) trees and (B) woody shrubs collected from swamp-peat forest of Muara Siran, Kutai Kertanegara, Indonesia

Since the purpose of this research was to find out the energy potency of wood biomass, a series of laboratory tests have been conducted to evaluate the proximate, ultimate and also calorivic value of the sample. The results indicated the high proportion of volatile matter in biomass of trees and shrubs (70.04\%) (Table 4). These high values allow biomass to get ignited easily. The high volatile matter (from 70 to $86 \%$ ) will improve the combustion rate of the biomass during the devitalization phase. On the contrary, low volatile matter causes high smoke from incomplete combustion, and it also releases toxic gases (Van Loo and Koppejan 2008). Volatile matter and fixed carbon were also known to play important roles in flame stability during combustion (Virmond et al. 2012). The results also showed low average value of ash content $(1.98 \%)$. The low ash content leads to better suitability of fuels for thermal utilization. In contrast, high ash content causes high dust emissions and negatively affects combustion efficiency (Ivanova et al. 2018). 
Table 4. Proximate analysis of biomass of plant species collected from swamp-peat forest of Muara Siran, Kutai Kertanegara, Indonesia

\begin{tabular}{|c|c|c|c|c|c|}
\hline \multicolumn{2}{|c|}{ Plant species } & \multirow{2}{*}{$\begin{array}{c}\text { Volatile } \\
\text { matter } \\
(\%)\end{array}$} & \multirow{2}{*}{$\begin{array}{c}\text { Fixed } \\
\text { carbon } \\
(\%)\end{array}$} & \multirow{2}{*}{$\begin{array}{c}\text { Ash } \\
\text { content } \\
(\%)\end{array}$} & \multirow{2}{*}{$\begin{array}{c}\text { Calorific } \\
\text { value } \\
(\mathrm{kCal} / \mathrm{kg})\end{array}$} \\
\hline L & name & & & & \\
\hline$\overline{A . d u m o s a}$ & Kayu har & 73.71 & 12.23 & 1.00 & 4327 \\
\hline A. elmeri & & 74.53 & 12.28 & 0.43 & 4690 \\
\hline A. longifolius & Terap hutan & 68.52 & 15.85 & 3.38 & 4563 \\
\hline C. odorata & Ken & 9.53 & 12.46 & 2.41 & 4230 \\
\hline C. brachiata & $\mathrm{Bak}$ & 7.48 & 16.75 & 1.42 & 4661 \\
\hline C. rotundatus & Per & 8.73 & 14.09 & 2.15 & 4350 \\
\hline D. excelsa & Sim & 5.88 & 17.71 & 3.72 & 4539 \\
\hline D. dao & & 77 & 13 & 2.31 & 4407 \\
\hline E. $c 1$ & Sen & 73 & 14.79 & 0.57 & 4664 \\
\hline E. $n t$ & & 57 & 13.80 & 1.84 & 4491 \\
\hline F. hispida & Kel & & 14.19 & 2.64 & 4532 \\
\hline F. $r$ & & & 16 & 0.58 & 5408 \\
\hline G. $b$ & & & 13.99 & 0.84 & 4525 \\
\hline G. $n$ & $\mathrm{Ma}$ & 71.19 & 15.76 & 0.91 & 4857 \\
\hline K. $I$ & & & 13 & 0.60 & 4634 \\
\hline L. & & & 15.91 & 2.52 & 4822 \\
\hline L. il & Mal & 58 & 14.62 & 2.52 & 4360 \\
\hline L. robusta & Tiju & 68.74 & 14.33 & 4.76 & 4287 \\
\hline$O . s$ & & & 14 & 1.87 & 4619 \\
\hline P. $g$ & & 69 & 14 & 1.55 & 4522 \\
\hline icum & & & 18.25 & 1.52 & 5213 \\
\hline S. balangeran & $\mathrm{Kah}$ & & 15.63 & 4.95 & 4432 \\
\hline tilimbum & & & & 1.94 & 4678 \\
\hline nthum & & & 16 & 2.7 & 4616 \\
\hline T. $o b$ & Pela & 74.44 & 12.18 & 1.38 & 4507 \\
\hline V. umbonata & $\mathrm{Ma}$ & & 15.96 & 1.43 & 4672 \\
\hline$V$. pinnata & & & 15.37 & 1.37 & 4550 \\
\hline & & 70.04 & 14.91 & 1.98 & 4598 \\
\hline
\end{tabular}

Moreover, from the ultimate analysis, we found that the average value of carbon, hydrogen and oxygen contents of wood biomass was $42.58 \%, 5.32 \%$, and $37.84 \%$, respectively (Table 5). The average of carbon, hydrogen and oxygen contents of plant biomass collected in the current study indicate that they belong to good quality of fuel biomass, and suitable to be used as green energy feedstock. Wood biomass could be used as fuel/green energy when the carbon content varied between $30-60 \%$, 5 $6 \%$ of hydrogen, $30-40 \%$ of oxygen, and the other elements are less than 1\%, respectively (Ivanova et al. 2018).

Furthermore, among twenty-seven samples tested, highest calorivic value of wood biomass was obtained from F. rukam $(5408 \mathrm{kCal} / \mathrm{kg})$ which was followed by $P$. javanicum $(5213 \mathrm{kCal} / \mathrm{kg})$ and $G$. nervosa $(4857 \mathrm{kCal} / \mathrm{kg})$, respectively. Interestingly, these plant biomass were not used locally as firewood materials (Table 4). Instead, they were used as traditional herbal medicine, construction wood, and furniture materials. In contrast, the lowest calorific value was obtained from $C$. odorata $(4230$ $\mathrm{kCal} / \mathrm{kg}$ ). This phenomenon was acceptable, since we knew that suitability of wood biomass as energy feedstock was not directly linked only to a single factor such as calorific value, but it should be connected and combined with other energy properties. According to McKendry (2002) and Huhtinen (2005), a combination of properties such as moisture content, calorific value, fixed carbon, volatile matter, ash content and chemical composition of wood biomass are important and should be considered for dry biomass conversion process.
Table 5. Ultimate analysis of biomass of plant species collected from swamp-peat forest of Muara Siran, Kutai Kertanegara, Indonesia

\begin{tabular}{|c|c|c|c|c|}
\hline \multicolumn{2}{|c|}{ Plant species } & \multirow{2}{*}{$\begin{array}{c}\text { Carbon } \\
(\%)\end{array}$} & \multirow{2}{*}{$\begin{array}{c}\text { Hydrogen } \\
(\%)\end{array}$} & \multirow{2}{*}{$\begin{array}{c}\text { Oxygen } \\
(\%)\end{array}$} \\
\hline Latin name & Local name & & & \\
\hline A. dumosa & Kayu harang & 41.33 & 5.21 & 38.80 \\
\hline A. elmeri & Medang & 41.73 & 5.26 & 39.21 \\
\hline A. longifolius & Terap hutan & 42.96 & 6.03 & 37.43 \\
\hline C. odorata & Kenanga & 39.57 & 4.96 & 36.88 \\
\hline C. brachiata & Bakau & 43.63 & 5.73 & 37.21 \\
\hline C. rotundatus & Perepat & 41.34 & 5.11 & 37.78 \\
\hline D. excelsa & Simpur & 43.91 & 5.73 & 36.57 \\
\hline D. dao & Sengkuang & 41.29 & 5.17 & 38.44 \\
\hline E.cyclocarpum & Sengon buto & 42.67 & 5.17 & 39.12 \\
\hline E. nitida & Bunga & 41.35 & 5.15 & 38.26 \\
\hline F. hispida & Kebolo & 42.63 & 5.23 & 37.96 \\
\hline F. rukam & Rukam & 44.73 & 5.47 & 38.61 \\
\hline G. bancana & Asam gendis & 41.56 & 5.18 & 38.41 \\
\hline G. nervosa & Manggis hutan & 42.77 & 5.40 & 38.51 \\
\hline K. hospita & Tahongai & 45.62 & 5.52 & 38.25 \\
\hline L. speciosa & Bungur & 45.33 & 5.13 & 36.61 \\
\hline L. indica & Mali & 41.47 & 5.14 & 38.09 \\
\hline L. robusta & Tiju & 40.40 & 5.01 & 37.08 \\
\hline O. sumatrana & Binuang & 41.09 & 5.10 & 37.74 \\
\hline P. galeata & Temberas & 41.65 & 5.18 & 38.43 \\
\hline P. javanicum & Bayur & 42.33 & 5.47 & 37.00 \\
\hline S. balangeran & Kahoi & 41.84 & 5.23 & 35.80 \\
\hline S.caudatilimbum & Bluma & 44.78 & 5.06 & 37.73 \\
\hline S. chloranthum & Bumbun & 44.59 & 5.92 & 37.26 \\
\hline T. obovata & Pelawan & 41.63 & 5.25 & 39.14 \\
\hline V. umbonata & Mas intan & 43.86 & 5.42 & 37.45 \\
\hline \multirow{2}{*}{$V \cdot$ pinnata } & Laban & 43.73 & 5.53 & 38.00 \\
\hline & Average & 42.58 & 5.32 & 37.84 \\
\hline
\end{tabular}

The wood biomass properties should be considered as a unit of energy factor to give an appropriate indication of suitability of wood biomass to be used as green energy feedstock. Based on this condition, twenty-three tree and four shrub species were evaluated completely. The results showed that $T$. obovata exhibit the highest suitability to be used as energy feedstock indicated by the highest energy production of 4.60 MWh per ton of dry biomass, , followed by L. indica (4.56 MWh/ton), D. excelsa (5.52 MWh/ton), F. rukam (4.20 MWh/ton), P. galeata (3.66 MWh/ton), S. caudatilimbum (3.61 MWh/ton), A. elmeri (3.59 $\mathrm{MWh} /$ ton), G. nervosa (3.49 MWh/ton) and G. bancana (3.42 MWh/ton) (Figure 3). The high density of wood species very much correlated with and clearly affected the high value of energy potency. Similar phenomenon was also reported from the wood biomass collected from the lowland community forest (Amirta et al. 2016a). In contrast, the fast-growing tree and shrub species, such as $K$. hospita (1.76 MWh/ton), $C$. odorata (1.36 MWh/ton) and $O$. sumatrana $(1.17 \mathrm{MWh} / \mathrm{ton})$, showed lower energy potency. The most dominant plant species, $S$. balangeran gave only $2.96 \mathrm{MWh}$ energy per ton of dry biomass and it was classified in the middle group of plant species suitable as the green energy feedstock, along with other species, such as C. brachiata, C. rotundatus, $P$. javanicum, V. umbonata, L. speciosa, V. pinnata, and A. longifolius. Due to suitable energy properties, growth rate and also adaptability of this woody biomass, we really believe that they can be exploited to support sustainable supply of biomass feedstock for the green electricity program in the area. 


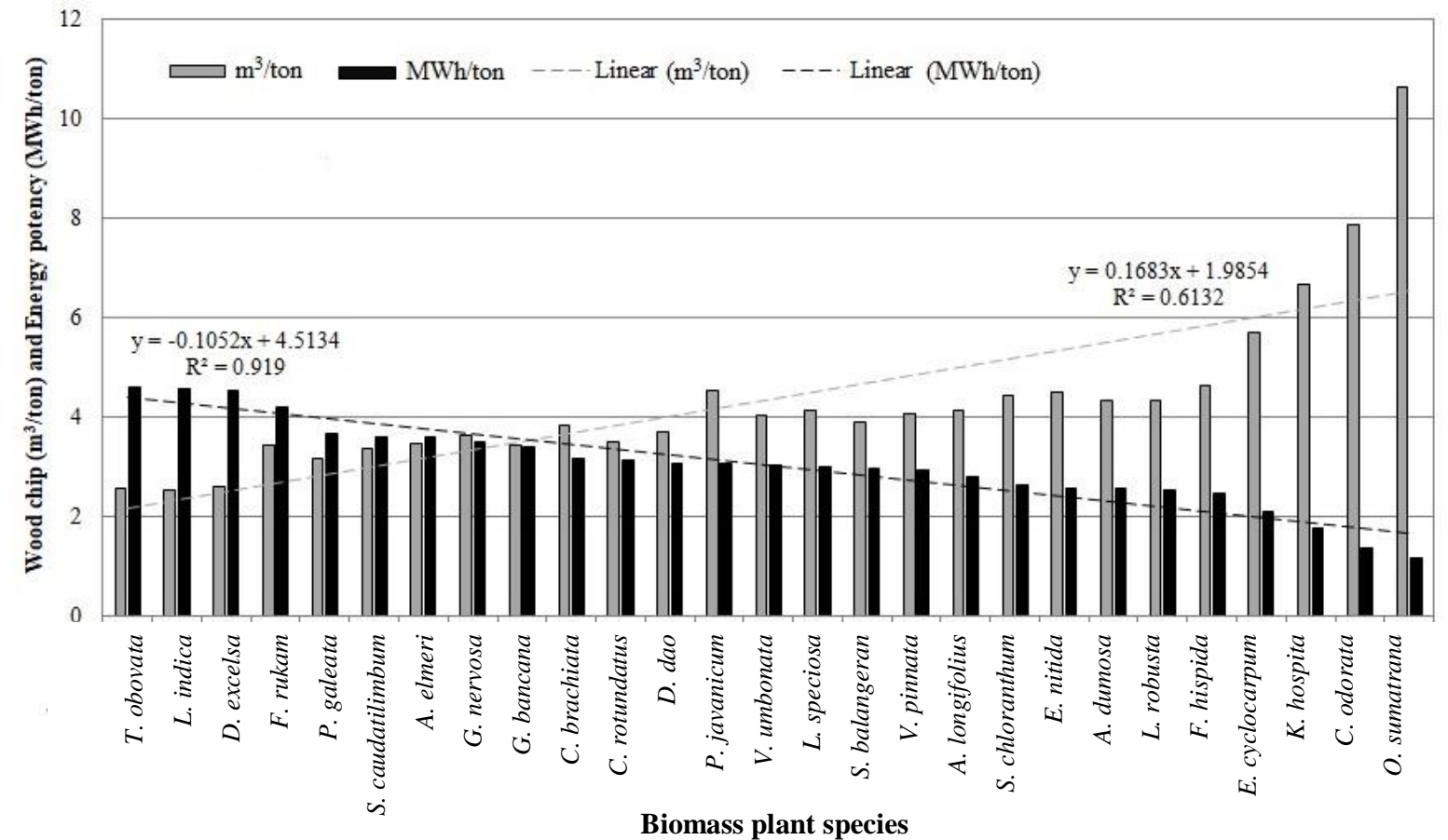

Figure 3. Comparison between wood chip conversion ratio and energy potency from tree and shrub species collected from swamp-peat forest of Muara Siran, Kutai Kertanegara, Indonesia

\section{ACKNOWLEDGEMENTS}

This work was financially supported by the grants of Islamic Development Bank (IsDB) (Grant No. $339 / \mathrm{UN} 17.11 / \mathrm{PI} / 2017$ for RA) and the Ministry of Research and Higher Education of IndonesiaRISTEKDIKTI (Grant No. 135/UN17.41/KL/2018 for RA) for Mulawarman University, Indonesia. We are grateful to Mr. Aspian Noor, Bioma Foundation, Samarinda for valuable discussions on the local basic policy of wood biomass utilization for energy and electricity in swamppeat forest of Muara Siran Village.

\section{REFERENCES}

Amirta R, Yuliansyah, Angi EM, Ananto BR, Setiyono B, Haqiqi MT, Septianan HA, Londong $M$ and Oktavianto RN. 2016a. Plant diversity and energy potency of community forest in East Kalimantan, Indonesia: Searching for fast-growing wood species for energy production. Nusantara Biosci 8 (1): 22-31.

Amirta R, Nafitri SI, Wulandari R, Yuliansyah, Suwinarti W, Candra KP, Watanabe T. 2016b. Comparative characterization of Macaranga species collected from secondary forests in East Kalimantan for biorefinery of unutilized fast-growing wood. Biodiversitas 17 (1): 116-123.

Arung ET, Kusuma IW, Purwatiningsih S, Roh SS, Yang CH, Jeon S, Kim YU, Sukaton E, Susilo J, Astuti Y, Wicaksono BD, Sandra F, Shimizu K, Kondo R. 2009. Antioxidant Activity and Cytotoxicity of the Traditional Indonesian Medicine Tahongai (Kleinhovia hospita L.) Extract. J Acupunct Meridian Stud 2 (4): 306-308,

Arung ET, Amirta R, Zhu Q, Amen Y, Shimizu K. 2018. Effect of wood, bark and leaf extracts of Macaranga trees on cytotoxic activity in some cancer and normal cell lines. J Indian Acad Wood Sci 15 (2): 115-119.

Albashabsheh, NT and Stamm JLH. 2019. Optimization of lignocellulosic biomass-to-biofuel supply chains with mobile pelleting. Transportation Research Part E: Logist Transport Rev 122: 545-562.

Brammer IG and Bridgwater AV. 2002. The influence of feedstock drying on the performance and economics of a biomass gasifier-engine CHP System. Biomass Bioenerg 22: 271-81.

De Oliveira JL, da Silva JN, Pereira EG, Filho DO, Carvalho DR. 2013. Characterization and mapping of waste from coffee and eucalyptus production in Brazil for thermochemical conversion of energy via gasification. Renew Sust Energ Rev 21: 52-58.

Dillen SY, Djomo SN, Al Afas N, Vanbeveren S, Ceulemans R. 2013. Biomass yield and energy balance of a short rotation poplar coppice with multiple clones on degraded land during 16 years. Biomass Bioenerg, 56: 157-165.

Fiala M and Bacenetti J. 2012. Economic, energetic and environmental impact in short rotation coppice harvesting operations. Biomass Bioenerg 42: 107-113.

Francescato F, Antonini E, Bergomi LZ. 2008. Wood Fuels Handbook: Production, Quality Requirements, Trading. AIEL-Italian Agriforestry Energy Association, Legnaro. Italy.

García SG and Bacenetti J. 2019. Exploring the production of bio-energy from wood biomass. Italian case study. Sci Total Environ, 647: 158168.

Ghaley BB and Porter JR. 2014. Determination of biomass accumulation in mixed belts of Salix, Corylus and Alnus species in combined food and energy production system. Biomass Bioenerg 63: 86-91.

Han SH and Shin SJ. 2014. Investigation of solid energy potential of wood and bark obtained from four clones of a 2-year old goat willow. Frontier in Energy Res 2 (5): 1-6.

Hauk S, Wittkopf S, Knoke T. 2014. Analysis of commercial short rotation coppices in Bavaria, southern Germany. Biomass Bioenerg, 67: 401-412.

Haverkamp MW and Musshoff O. 2014. Are short rotation coppices an economically interesting form of land use? A real options analysis. Land Use Policy 38: 163-174. 
Huhtinen M. 2005. Wood biomass as fuel. In Material for 5EURES Training sessions; Huhtinen M (ed.). European Commission under the Intelligent Energy-Europe Programme, Brussels, Belgium.

Ivanova T, Muntean A, Havrland B, Hutla P. 2018. Quality assessment of solid biofuel made of sweet sorghum biomass. Contemporary Research Trends in Agricultural Engineering, BIO Web of Conferences 10,02007.

Jiankun H, Zhiwei,Y and Da, Z. 2012. China's strategy for energy development and climate change mitigation. Energ Pol 51: 7-13.

Krzyzaniak M, Stolarski MJ, Szczukowski S, Tworkowski J, Bieniek A Mleczek M. 2015. Willow biomass obtained from different soils as a feedstock for energy. Ind Crop Prod 75: 114-121.

Kumar A, Kumar N, Baredar P, and Shukla A. 2015. A review on biomas energy resources, potential, conversion and policy in India. Renew Sust Energ Rev 45: 530-539.

Lattimore B, Smith C, Titus B, Stupak I, Egnell G. 2009. Environmenta factors in woodfuel production: opportunities, risks, and criteria and indicators for sustainable practices. Biomass Bioenerg 33: 1321-1342.

McKendry P. 2002. Energy production from biomass (part 2): conversion technologies. Bioresource Technol 83: 47-54.

Niemczyk M, Kaliszewski A, Jewiarz M, Wróbel M, Mudryk K. 2018. Productivity and biomass characteristics of selected poplar (Populus spp.)

cultivars under the climatic conditions of northern Poland. Biomass and Bioenerg, 111: 46-51.

Parikh L, Channiwala SA, Ghosal GK. 2005. A correlation for calculating HHV from proximate analysis of solid fuels. Fuel 84: 487-94.

Parikh L, Channiwala SA, Ghosal GK. 2007. A correlation for calculating elemental composition from proximate analysis of biomass materials. Fuel 86: 1710-1719.

Pereira EG, Da Silva JN, Oliveira JL., Machado CS. 2012. Sustainable energy: a review of gasification technologies. Renew Sust Energ Rev 16: 4753-4762.

Pérez S, Renedo CJ, Ortiz A, Delgado A, Fernández A. 2014. Energy potential of native shrub species in northern Spain. Renew Energ 62 79-83.

Routa J, Kellomäki S, Strandman H. 2012. Effects of Forest Managemen on Total Biomass Production and CO Emissions from use of Energy Biomass of Norway Spruce and Scots Pine. Bioenerg Res 5: 733-747.

Sims REH, Maiava TG, Bullock BT. 2001. Short rotation coppice tree species selection for wood biomass production in New Zealand. Biomass Bioenerg 20 (5): 329-335
Sims REH and Venturi P. 2004. All-year-round harvesting of short rotation coppice eucalyptus compared with the delivered costs of biomass from more conventional short season, harvesting. Biomass Bioenerg 26 (1): 27-37.

Sixto H, Cañellas I, Arendonk JV, Ciria P, Camps F, Sánchez M, González MS. 2015. Growth potential of different species and genotypes for biomass production in short rotation in Mediterranean environments. Forest Ecol Manag 354: 291-299.

Thomy Z, Yulisma A, Harnelly E, Susilowati A. 2018. Molecular phylogeny of trees species in Tripa Peat Swamp Forest, Aceh, Indonesia inferred by 5.8S nuclear gen. Biodiversitas 19 (4): 11861193

Van Loo S, Koppejan J. 2008. The Handbook of Biomass Combustion and Co-Firing. Earthscan, London.

Vassilev SV, Baxter D, Andersen LK., Vassileva CG. 2010. An overview of the chemical composition of biomass. Fuel 89: 913-933.

Virmond E, De Sena RF, Albrecht W, Althoff CA, Moreira RF, Jose' HJ. 2012. Characterisation of agroindustrial solid residues as biofuels and potential application in thermochemical processes. Waste Manag 32 (10): 1952-1961.

Watanabe T, Watanabe T, Amirta R. 2008. Lignocellulosic Biorefinery for Sustainable Society in Southeast Asia. Proceeding of the $1^{\text {st }}$ Kyoto-LIPI-Southeast Asian Forum, Jakarta.

Wihersaari M. 2005. Greenhouse gas emissions from final harvest fuel chip production in Finland. Biomass Bioenerg 28: 435-443.

Wiryono, Puteri VNU, Senoaji G. 2016. The diversity of plant species, the types of plant uses and the estimate of carbon stock in agroforestry system in Harapan Makmur Village, Bengkulu, Indonesia. Biodiversitas 17 (1): 249-255.

Widjaya ER, Chen G, Bowtell L, Hills C. 2018. Gasification of nonwoody biomass: A literature review. Renew Sust Energ Rev 89: 184193.

Yudego BM, Arevalo J, Yáñez OD, Dimitriou I, Haapala A, Filho ACF, Selkimäki M, Valbuena R. 2017. Wood biomass potentials for energy in northern Europe: Forest or plantations?. Biomass Bioenerg 106: 95-103

Yulisma A, Thomy Z, Harnelly E. 2018. Phylogenetic relationships within families Myrtaceae in Tripa swamp forest using internal transcribed spacer (ITS). Jur Nat 18 (2): 65-71. 